\title{
The priorities of public libraries at the onset of the third millennium
}

\author{
Ana R. Pacios \\ Library Science and Documentation Department, Carlos III University, \\ Madrid, Spain
}

\begin{abstract}
Purpose - This paper aims to show the main action areas to which public libraries are devoting their efforts and resources at the onset of the twenty-first century, despite their own particularities and needs.

Design/methodology/approach - The methodology is based on a comparative analysis on a sample of so-called "strategic" and "long-term" plans from US public libraries covering from 1998 through 2010. Of all identified priorities, those appearing in at least 40 per cent of the plans were used for the analysis. Thus, the paper narrowed the list of priorities down to the five most repeated ones in the sample of plans, and their peculiarities are set forth here.

Findings - The paper finds that, although the method used is a simple one and the results are limited to the set of libraries whose plans have been analysed, there are coincidences with some predictions in some papers on the role public libraries should play in the twenty-first century.

Originality/value - In the long term, this type of research permits comparison of trends among libraries from different countries and the monitoring of how they evolve with time. It can also be useful to library managers as a benchmark.
\end{abstract}

Keywords Public libraries, United States of America, Strategic planning

Paper type Research paper

\section{Introduction}

The changing environment affects libraries, in particular public libraries, which are forced to continuously try to adapt to fulfil their information, literacy, education, and culture mission. At this time of unprecedented changes - which will continue to happen, if we take into account the rapid evolution of information technologies and of social and demographic changes - one might ask how are public libraries are responding to them.

Planning allows libraries to adapt to changes efficiently, as it reduces uncertainty by anticipating possible problems - and helps to identify threats and future opportunities. It allows library managers to act proactively in the face of potential crises. The planning process materialises in a document called "strategic" or "long-term" plan, depending on library preference. These plans focus on the community served by the library, and include, among others elements, defining priorities and long-term objectives; i.e. the priority action lines where the library intends to focus its efforts - and therefore allocate its resources - during the years covered by the plan. A comparative analysis of the priority action areas of a sample of plans shows whether there are any coincidences and, as a function of the most frequent ones, allows the establishment of some common trends or areas of emphasis for public 
libraries during the early years of the twenty-first century. In the long term, with this type of research we can compare trends among libraries from different countries and to monitor how they evolve with time. It can be useful to library managers as a benchmark, and to compare the results of this work with what actually happens in the libraries whose plans have been analysed (a list of plans used in this paper can be seen in the Appendix). It would be appropriate to also have the users' opinions, to verify whether these findings correlate with their perceptions about the library.

\section{Objectives and methodology}

This paper aims to show the trends of priority action areas in public libraries during the early years of the third millennium, despite their own particularities and needs. To do this, I run a comparative analysis of 73 American public library plans found through a Google search. These plans have been gathered for a period of five years, from 2002 to 2006, to obtain a large sample covering the last years of the 20th century and the first years of the twenty-first. Both "strategic" and "long-term" plans have been selected, as these are the two most widely used expressions to refer to them. They vary in the number of years they cover - one, two, three, four, five, six and ten - mostly from year 2000 - although some start in 1998 - and no later than 2010. The most frequently planned period is 2001 to 2006 .

Plans are structured into sections or headings with names that sometimes differ. To select libraries' priority areas, I have picked up all sections with the following titles: Service Responses, Strategies, Goals and Objectives, Library Directions, Strategic Directions, Priorities, Strategic Goals, Key Areas, Key Strategic Issues, and Programs. I chose these sections because they best reflect the results the library tried to reach during the years covered by each plan. I could have also included "Vision", as it is supposed to reflect the strategic intent, the aspiration or desired future state of the library. I did not, however, because many plans lacked this section, and others that did have it often used rather ambiguous or not sufficiently specific language that made it difficult to assign them to a concrete library priority. Some examples of this are "to enjoy an intellectually and culturally rich life", or "guarantee the impartial provision of information".

Of the 73 gathered plans and, in particular, of each of the ten indicated sections, I analysed and identified the priorities, and introduced them in a database. In total, I identified 29 items as priorities. However, given the space limitation of this paper, I found it appropriate to focus on the items that were present in at least 40 per cent of the plans. Thus, I narrowed the list down to the five most repeated ones in my sample of plans, and their peculiarities are set forth here.

Although the method used is a simple one and the results are limited to the set of libraries whose plans have been analysed, there are coincidences with some predictions in some papers on the role public libraries should play in the twnety-first century. In the most recent literature, which is referenced at the end of this paper, other preferential attention areas shown are, for example, lifelong learning (O'Loan and McMenemy, 2005), planning, cooperation and sources of funding (Woodrum, 1989), and the library building, library as a second home (Worpole, 2004). 


\section{The five top issues for public libraries}

A library's priorities show the relation existing between the needs of the community, the services the library intends to provide to satisfy them, and the necessary resources. Priorities vary depending on what roles a library wishes to support in a given period of time. In the selected sample, references to priorities sometimes relate to services and sometimes to the necessary resources to provide such services, but both types of plans show clear coincidences. The result of the comparative analysis of plans is shown in Table I, which includes the five most frequent issues together with the number of times each is repeated as a percentage of the total 73 plans consulted.

As can be seen, priorities focus both on providing services (lifelong learning) and on finding the necessary resources to improve such provision (collection, building, and staff). They also refer management, a function that affects both services and resources, and therefore the library's final results or global performance. Below, I comment some of the most frequently covered aspects in relation with these five recurrent issues. It is worth knowing, as it may pose a question in the face of the continuous technological breakthroughs in our time, that the sixth place is for technology, which 37 per cent of plans include among their priorities. With respect to this priority, most libraries seek to obtain a better performance. They seek to use technology more intensively to improve and increase the use of their resources and services. They want their services to move outside the library building and be part of people's lives, getting into their homes, their workplaces, the means of transport they use, etc. Some authors have noticed this trend for the twenty-first century (Freedman, 2006; Ormes, 2001; Worpole, 2004).

\section{Collection and resources}

With respect to the collection, libraries fundamentally aim to acquire updated themes and titles, to keep them up to date, with a variety of themes, materials, formats and languages. They also aim to have a sufficient number of copies to meet all kinds of needs, whether related to work, education or decision making in personal life. Often this line of action goes arm in arm with "lifelong learning".

Libraries wish the collection to reflect the community's changes of interests and preferences, to represent society's diversity, its racial and ethnic mix, thus contributing to dialogue and tolerance among the different races. The Hispanic community is quite numerous in some areas, and draws special attention in some of the plans consulted. For this reason, there are also many programs addressed to people of all ages to learn Spanish. Other programmes aim to foster reading in what it is considered their second language - English - and libraries intend to acquire materials in various formats that are appropriate to meet the needs of different groups. The development and management of a good language collection is a priority with many libraries.

Priority issues

Percentage

Collection and resources

Lifelong learning

Building, facilities, and equipment

46

Staff

Management 
Another concern shown by the plans is the space available to store the collection. They aim to have archives y repositories to preserve publications, for example relating to local history. Repositories are made available to the local government, as well as to various institutions and organisations sharing with the library the same or similar sphere of activity.

The following are some of the most frequently quoted collection-related objectives:

- Increasing the number of copies of reading materials for children and the young.

- Increasing the use of reading materials of specific theme areas, and their circulation (sometimes there is even a coincidence as to the intended percentage, an annual 5 per cent).

- Increasing the investment to purchase new materials for the collection. In some cases, the aim is to spend 70 per cent of the library budget.

- Developing more programmes and activities addressed to people of all age segments in the community, to help them acquire skills and interests that will allow them to succeed in school and in other learning-related activities.

- Finding ways to obtain new titles: library friends, relevant writers, donations, etc.

- Increasing the acquisition of information and resources in electronic format: books, CDs and DVDs, videotapes, especially for children and the young. Some libraries aim to have 80 per cent of the titles included in the Children's Catalogue and the ALA Notable Children's Book List. These bibliographies are also used, in some cases, as a measure of performance rather than as selection tools.

- Innovating and adding new digital formats.

- Increasing the history, literature, and reading materials collections.

- Designing summer reading programmes.

- Cooperating with teachers of educational centres in preparing reading campaigns.

- Programming specific reading activities for the elderly.

In general, libraries aim to efficiently manage the collection by means of examining, assessing and later adapting it to obtain collections that are appropriate, relevant, up to date, and accessible. They use different strategies for that purpose, including:

- Identifying and, where appropriate, eliminating duplication of works.

- Implementing online access to the collection (web version of the catalogue).

- Developing virtual collections.

- Knowing annually, through surveys, users' interests and needs.

- Analysing loan-reservation trends, to determine what types of materials are needed and recommend strategies to satisfy these needs.

Finally, with respect to this first priority, the collection development manager appears, linked to the collection-related objectives. This manager is considered essential to centralise some collection functions, especially in libraries that are part of a network or system of libraries belonging to a specific territory. 


\section{Lifelong learning}

Lifelong learning, or ongoing education, includes all learning activities done during a person's life with the purpose of improving knowledge, competences and skills from a personal, civic, social, or employment-related perspective. It is now a challenge in today's society, as ongoing education and updating and renewing professional competences have become strategically important to develop the human capital in organisations. That is the reason why international organisations have considered it a key factor to come into the twenty-first century. Thus, the European Council at its Lisbon meeting in March 2000, concluded that "lifelong learning must accompany a successful transition to a knowledge-based economy and society".

In this comparative analysis of plans, the library also joins the institutions that cooperate to build a new, dynamic environment to promote the habit of learning. A good reflection of this is that lifelong learning comes as the second priority in our sample. In some plans it comes together with other services, such as general information - i.e. the capacity to respond properly to various issues related to work, education, and private life - as well as reading and basic information literacy.

Libraries' main line of action, as stated in their plans, is to become centres facilitating independent, ongoing learning, thus contributing to the personal and social development of people of all ages, to the development of opportunities, and to satisfy the community's wish to understand its and other peoples' cultural heritage through literature, history, the arts and poetry. With their materials, resources, technology and activities, they teach how to search for and evaluate information, promote the pleasure of reading, and foster people to acquire skills that will allow them to critique constructively.

Some objectives and strategies related to this line of action aim, for example, to:

- learning the techniques to search for and obtain the right information;

- language self-training;

- creating spaces to facilitate study to people on non government-regulated education programmes;

- programming activities to promote the pleasure of reading, especially among children; and

- engaging staff specialised in creating educational materials, in particular those on the web page.

\section{Building, installations and equipment}

Plans where the library building and its installations receive preferential attention show that they significantly lack space in relation to the users' new needs and the building's poor flexibility. Another common perception is librarians' determination to turn libraries into a key space in the life of the community, a centre allowing the development of all types of activities and encounters. Plans also show that an increase in library space has a direct impact on the level of use and appreciation by the users.

In general terms, libraries focus their aspirations on extending the space available for users and improving their equipments. They consider this necessary to start group programmes and meetings. The space must be multipurpose, and flexible to accommodate groups of people with different ages and different activities. Lack of space in some libraries leads them to adopt interim solutions, such as acquiring 
moveable architectural elements - walls, for example - so that the available space can be adapted to different uses and needs. Others try to gain space by reducing the collections on paper; also, if they have the opportunity, by extending the library. All these strategies aim at promoting and fostering library use.

Some libraries justify the need for space by adding, as an appendix to their plans, their users' ideas, suggestions and requests in this respect. The following are some examples of what users want in relation to library space:

- spaces where the young can meet and listen to music;

- cafeterias and other areas where they can eat;

- study areas;

- group-work rooms;

- spaces to just sit down and chat;

- spaces and opportunities for social interaction, public library as a meeting place;

- spaces specifically for teenagers;

- changes in the way spaces are arranged;

- more places for internet access, with more computers; and

- spaces for quiet reading.

Therefore, despite users' high level of use of and satisfaction with online services, they demand spaces to establish relations and interact with other individuals. They see the library as a physical space where they can share ideas and communicate face to face.

Users also criticise and ask for improvements on library equipment and aspect. Thinks they ask for include repairs, redecoration, change of signs, colour photocopy machines, improved lighting in the reading areas, improved furniture, soundproofing certain areas, coffee machines, etc.

\section{Staff}

Libraries want more and better qualified librarians. Their final goal is to provide a high level of service. It is commonly inferred from many plans that there is a shortage of staff to attend users. These, especially the younger ones requiring more attention, also express that demand through focus groups.

The most frequently mentioned objectives as regards human resources are addressed to improve some processes and techniques. These include, among others:

- recruiting and retaining qualified staff;

- providing opportunities for ongoing professional development and training;

- ensuring good internal communication, among all levels and departments; (preparing communication manuals is a common way to achieve it);

- developing guidance programs for new staff, to familiarise them with the manuals of policies and procedures;

- maintaining competitive salaries;

- reviewing staff policies;

- evaluating all employees; 
- analysing the times staff devote to activities;

- reviewing and updating staff manuals;

- reviewing and adapting existing job descriptions; and

- creating new jobs adapted to new needs.

Plans include many references to staff training, thus showing libraries as organisations that learn. Specifically, the most demanded staff training relates to new technologies and on searching information to make it available to the users.

\section{Management}

Under this heading I have considered library aspirations to implement different techniques aiming to improve and increase the performance of resources, and thus their efficacy and efficiency. Some libraries consider a priority in their plans to properly apply management techniques to obtain a good performance.

Management plans cast an increasingly more participative image of the library. Things are normally done by interdepartmental working groups, which contribute to increased productivity, innovation, creativity, and problem solving. This is particularly reflected by the complementary material appended to some plans, where there are ideas, suggestions and comments from librarians with different professional categories, collected in focus groups created to find out the areas that call for preferential planning attention from the libraries.

The ultimate goal of some of the management techniques used is to foster a better knowledge of the library services and make them more visible. Thus, with the communication and marketing plans, for example, libraries aim to identify new segments of potential users, customise the messages sent to each of them, find new communication channels to make the library known, and better communicate the value of the services, their relevance and the results produced by the library in its community.

Benchmarking is a technique now extensively used by libraries. Librarians search for and pay attention to the strategies used by other libraries, to adapt them and make them suitable to their own particular situation. They are mostly interested in the marketing plans that were successful in other libraries.

Another important point is cooperation with other institutions, at both local and regional levels. The aim is often to establish links with teaching centres to help them in their educational work. Public relations are therefore a key success factor to reach that goal. Knowing the curricula and syllabuses is one of the basic starting points to adapt programmes, activities and services. Cooperation and association strategies are also addressed to other libraries, to share and increase programs, services and collections.

Planning itself is another priority for some libraries. They want planning to become a habit, to continue to make the right decisions. Establishing priorities shows itself as essential to prepare a real budget that will ensure good results at fiscal-year end. Monitoring the progress of the strategic plans, every three to four years, is also relevant for some libraries. It includes reviewing the mission, extending, if applicable, the vision, and defining new goals to reach them, as well as updating the working planning documents.

Evaluation is undoubtedly another key activity for library managers. Its purpose is to know the use and efficiency of services and programmes, their real performance. 
Managers want evaluation to become a systematic activity, developing policies and procedures to regularly evaluate all key areas, to ensure the leadership of the library and the quality of its services. Evaluation tries to reach all areas whose results are key - some, such as cooperation, less commonly covered by evaluation exercises - to try to find out their efficiency.

Finally, financing provides another set of management-related goals and objectives. Obtaining an appropriate budget to face the needs of the library is a common concern in many strategic plans. Thus we have the implementation of annual campaigns by some libraries to find new sources of funds (selling books, establishing associations, obtaining donations, finding sponsors, etc.).

\section{Conclusions}

A comparative analysis of plans from the libraries in our sample depicts a library that starts the twenty-first century committed to specific realities, close to the citizens, very much involved in social issues. It wants, above all, to offer updated information that is useful for ongoing learning. Although libraries have long moved from possessing the information resources to gaining access to them, their utmost priority is having a good collection on site that is sufficient, balanced, complete, and of quality. Ongoing education has strategic importance and it is one of libraries' preferential areas of attention. It does not only aim to provide the right information to learn, but also facilitates and fosters the development of competences and skills to interpret that information. Users and library staff are the axes around which all library activity rotates. Technology, although it is important and is present in the plans, is not among the five preferential areas of attention, perhaps because the libraries in the sample already have good technological equipments. There is, however, a general interest to improve the performance of the available technology.

\section{References}

Freedman, M.J. (2006), "Public libraries in the internet age", EJournalUSA, March, available at: http://usinfo.state.gov/journals/itgic/0306/ijge/freedman.htm (accessed 22 November 2006).

O'Loan, S. and McMenemy, D. (2005), "The role of the 21st-century public library", Delivering Digital Services: A Handbook for Public Libraries and Learning Centres, Facet Publishing, London, pp. 3-18.

Ormes, S. (2001), "Public libraries focus: lights out and silver boots on", Ariadne, No. 27, available at: www.ariadne.ac.uk/issue27/pub-libs/ (accessed 27 November 2006).

Woodrum, P. (Ed.) (1989), Managing Public Libraries in the 21st Century, The Haworth Press, New York, NY.

Worpole, K. (2004), "21st century libraries: changing forms, changing futures", available at: www.cabe.org.uk/default.aspx? contentitemid $=526 \&$ field $=$ sitesearch\&term $=$ libraries \&type $=0$ (accessed 27 November 2006).

\section{Further reading}

Commission of the European Communities (2001), Communication from the Commission: Making a European Area of Lifelong Learning a Reality, COM (2001) 678 final, European Commission, Brussels, available at: www.ub.es/ub/europa/documents2/2_Comunicats_ de_la_Comissio/06_COM_Aptge_permanent.pdf (accessed 26 November 2006). 
Goulding, A. (2006), Public Libraries in the 21st Century: Defining Services and Debating the Future, Ashgate, Burlington, VT.

Lozano Díaz, R. (2006), La frdg lioteca pública del siglo XXI: atendiendo clientes, movilizando personas (Public Libraries in the 21st Century: Attending Clients, Mobilizing People), Trea, Gijón.

Molyneux, B. (2006), "Recent public library trends", SirsiDynix, 27 March, available at: www. imakenews.com/eletra/mod_print_view.cfm?this_id $=554723 \& u=$ sirsi\&issue_id $=$ 000112999\&show =F,T,T,T,F,Article,F,F,F,F,T,T,F,F,T,T (accessed 27 November 2006).

Rodríguez Paris, E. (2004), "Frdg lioteca pública y sociedad: Adecuación al entorno", ("Public libraries and society: adapting to the environment"), available at: www.anabad.org/ archivo/docdow.php?id $=140$ (accessed 25 November 2006).

\section{Appendix}

Below is a list of plans consulted to prepare this paper. If they can still be accessed, their URL is also included.

\section{Long-range plans}

- Marshall Public Library. Long-Range Plan 1999-2003;

- Marion County Public Library System - Long-Range Plan 2001-2006;

- Albert Wisner Public Library - Long-Range Plan of Service 2000-2004;

- Sammie Long Range Plan 1999-2004;

- Cross' Mills Public Library Long-Range Plan 2001-2005;

- Tuscarawas County Public Library Long-Range Plan for 2001-2003;

- St Joseph County Public Library Long-Range Plan 2000-2004;

- High Point Public Library - Long-Range Strategic Plan;

- Madison-Jefferson County Public Library - Long-Range Plan 2003-2006;

- Wilmington Memorial Library - Long-Range Plan FY2001-2005;

- Glen Ellyn Public Library - Long-Range Plan 2001-2003;

- Winnefox Library System - Annual Plan 2004;

- Walworth-Seely Public Library - Long-Range Plan;

- Bridgeport Public Library 2001-2005;

- Easton Public Library - Long-Range Plan 2003-2008: www.eastonlibrary.org/home/ long_range_plan.html;

- Corvallis-Benton County Public Library - Long-Range Plan 2002-2007: http://ibrary.ci. corvallis.or.us/corvallis/images/plan.pdf;

- Boston Public Library - Long-Range Plan 2000-2003: www.bpl.org/general/trustees/ longrangeplan.htm;

- Fairfield Public Library - Long-Range Plan 2001-2006: www.fairfieldpubliclibrary.org/ fiveyearplan.htm;

- Prairie du Sac Public Library - Library Service Plan 2000-2003: www.scls.lib.wi.us/pds/ about/longrange.html;

- Oak Lawn Public Library - Long-Range Plan: www.lib.oak-lawn.il.us/olpllrp.htm; 
- Mohawh Valley Library System - Plan of Service 2002-2006: www.mvls.info/admin/ pos-2001.pdf;

- Baldwinsville Public Library - Long-Range Plan 1998-2000: www.bville.lib.ny.us/ mission.htm;

- Waverly Public Library- Long-Range Plan FYE 2003-2005: http://city.waverlyia.com/ library_plan.asp;

- Gates Public Library - 3rd. Long-Range Plan 2003-2007: www.gateslibrary.org/ longrangeplans/lrplan3.php;

- Montana State Library - Long-Range Plan 2002-2007: http://msl.state.mt.us/admin/ lrplan/lrp.html;

- Albany Public Library Long-Range Plan 2002-2006: www.uhls.org/uhls/about/aplm_plan. cfm;

- Rowan Public Library - Long-Range Plan for 2002-2006: www.lib.co.rowan.nc.us/IN/ longrangeplan.htm;

- Westford Public Library - Long-Range Plan 2002-2006: www.westford.lib.vt.us/ 2002-2006\%20LRP.pdf;

- Appleton Public Library Long-Range Plan 2000-2004: www.apl.org/policies/plan99.html;

- Fort Worth Public Library Long-Range Services Plan: www.fortworthgov.org/library/ lrsp.htm;

- Cahokia Public Library District - Long-Range Plan 2004-2008: www.cahokialibrary.org/ Long \% 20Range \%20Plan \%202004\%20with\%20CPLD\%20Logo\%20BW\%20640.pdf;

- Scarborough Public Library - Long-Range Plan 2002-2004: www.library.scarborough.me. us/pdf/trustees/LRP2002-04.pdf;

- Central Florida Library Cooperative - Long-Range Plan 2001-2006: http://cflc.net/CFLC/ lrp98.htm;

- Watertown Free Public Library Long-Range Plan FY1999-FY2004: www.watertownlib. org/long.htm;

- Bella Vista Public Library - Long-Range Plan 2002-2006: www.bvpl.org/plan.htm;

- Medfield Memorial Public Library - Long-Range Plan 2001-2006: www.medfieldlibrary. org/library/longrange_plan.html;

- LaGrange Public Library - Long-Range Plan: www.lagrangelibrary.org/longrangeplan/ lrpindex.html; and

- Mid-Wisconsin Federated Library System Long-Range Plan: www.mwfls.org/ longrangeplan.html

\section{Strategic plans}

- Alberta Public Library Electronic Network - Strategic-Plan Outline 2001-2003;

- Brantford Public Library - Strategic Plan 2001-2003;

- The Mendon Public Library - Strategic Plan 2000-2005;

- Alameda County Library Strategic Plan;

- Thunder Bay Public Library - Strategic Plan 2002-2005;

- San Francisco Public Library Strategic Plan 2001-2004;

- El Paso Public Library Strategic Plan 2002-2003; 
- Dictrict of Columbia - Strategic Plan FY 2002-2004: www.dc.gov/strategic-plan/dcpl. shtm;

- Glencoe Public Library Strategic Plan 2002-2005: www.glencoe.lib.il.us/webplan.htm;

- Brooklyn Public Library's Strategic Plan 2001-2006: www.brooklynpubliclibrary.org/pdf/ Plan $\% 20$ of $\% 20$ Service.pdf;

- Morrill Public Library Strategic Plan 2002-2004: http:/skyways.lib.ks.us/pathway/ morrill_introduction.html;

- Pawtucket Public Library - Strategic Plan 2002-2006: www.pawtucketlibrary.org/ strategicplan.htm;

- Waterford Public Library - Strategic Plan 2001-2006: www.waterfordpubliclibrary.org/ contents.html;

- James Prendersgast Library Strategic Plan 2002-2006: www.cclslib.org/ jamesprendergast5yearplan.html;

- Redwood City Public Library - Strategic Plan 2002-2005: www.guilderlandpublic.info/ strategy.pdf;

- Oak Park Public Library Strategic Plan 2003-2007: www.oppl.org/about/plan.htm;

- Thunder Bay Public Library - Strategic Plan 2006-2008: www.tbpl.thunder-bay.on.ca/ internal.asp?id $=78 \&$ cid $=2525$;

- Willoughby-Eastlake Public Library - Strategic Plan 2002-2006: www.wepl.lib.oh.us/ strategic_plan.htm;

- Tucson-Pima Public Library Master Strategic Plan 2004-2009: www.lib.ci.tucson.az.us/ about/strategic/strategicplan.pdf;

- Nelson Municipal Library Strategic Plan 2003: www.library.nelsonbc.net/strategic.html;

- Westport Public Library Strategic Plan 2004-2007: www.westportlibrary.org/about/ publications/ WPL \%20Strategic\%20Plan\%202004-2007\%20August\%202005\%20Update.pdf;

- The City of Mountain View Public-Library Strategic Plan 2002-2007: www.ci.mtnview.ca. us/city_hall/library/general/general_information/strategic_plan.asp;

- San Antonio Public Library Strategic Plan: www.sanantonio.gov/library/strategicplan. asp?res $=800 \& v e r=$ true;

- Burlington Public-Library's Strategic Plan 2001-2004 and Strategic-Directions Plan 2005-2007: www.bpl.on.ca/pdf/stratplan05-07.pdf;

- St Charles Public Library. Strategic Plan 2000-2003: www.st-charles.lib.il.us/contact/ strategicplan.htm;

- St Charles City-County Library District - Strategic Plan 2000-2008: www.win.org/library/ library_office/reports/stratplan/index.html;

- Northeast Massachusetts Regional Library System Strategic Plan 2000-2005: www.nmrls. org/strategicplan/plan/plan.html;

- Toronto Public Library's Strategic Plan 2004-2007: www.tpl.toronto.on.ca/abo_stp_index. jsp;

- Morton Grove Public Library Strategic Plan 2003-2005: www.webrary.org/inside/ stratplan1.html\#intro;

- District of Columbia Public Library Strategic Plan 2004-2006: www.dclibrary.org/dcp1/ stratpla/DCPL \%20Strategic\%20Plan\%20for\%20FY2002-2004_files/frame.htm; 
- Ann Arbor District Library - Strategic Planning 2004-2010: www.aadl.org/planning/ strategicplan;

- Marysville Public-Library Strategic Plan: www.marysvillelib.org/about/strategic_plan. php;

- Evanston Public-Library Strategic Plan 2000-2010: www.epl.org/library/strategic-plan-00. html; and

- Chicago Public Library 2010: www.chipublib.org/strategicplan/StrategicPlan_final.pdf

\section{Corresponding author}

Ana R. Pacios can be contacted at: anareyes.pacios@uc3m.es 